\title{
ラン藻の代謝改変によるバイオプラスチック増産 ラン藻代謝工学の新展開
}

ラン藻は，酸素発生型の光合成を行う細菌である（図 1). 淡水, 海水, 土壤から深海や温泉に至るまで，あら ゆる環境に生育していることが知られている，光合成を 行うことで, 光エネルギーと大気中の二酸化炭素の利用 が可能であることから，ラン藻を用いたバイオエネル ギー, バイオマテリアルの生産に期待が寄せられてい る. 現在では，スピルリナというラン藻種が，健康食品 および色素生産の目的で工業的に培養されているが，プ ラスチックなどの化学工業原料や燃料物質の生産には 至っていない．ラン藻による効率的で多様な物質生産系 を確立することで，化石燃料の使用を低減した二酸化炭 素の資源化が可能となる.

プラスチックは，現代社会には必要不可欠な物質であ るが，石油由来で合成されることから資源枯渇の問題が ある。また，プラスチックは使用後にゴミとして蓄積し ていくなどの問題も抱えている，そこで，従来のプラス チックの代替品として, バイオプラスチックの利用が萀 められている，バイオプラスチックとは，生物由来の有 機資源から作られたバイオマスプラスチックと，環境中 で分解される生分解性プラスチックのどちらかの性質を 有するプラスチックである。われわれが注目しているポ リヒドロキシアルカン酸（PHA）は，微生物が作り出 し, 生分解性があることから, 両方の性質を有するバイ

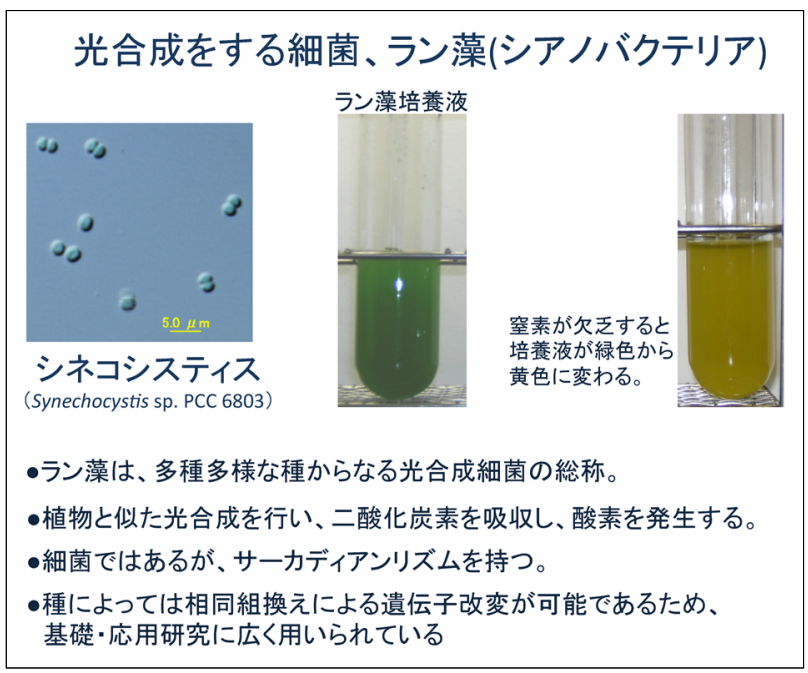

図 1 ロラン藻という生き物
オプラスチックである．PHAは，株式会社カネカによ り工業的に生産されているプラスチックである（商品 名：カネカバイオポリマー アオニレックス). PHA は，側鎖の構造によってさまざまな性質をもつが，われ われは，ラン藻が生産するPHAの一種であるポリヒド ロキシ酪酸（PHB）の増産を目指している.

ラン藻などの微生物は, 窒素やリンなどが久そする と, 休眠状態へと入っていくが，この際に炭素の貯蔵源 としてPHAを合成する。 ラン藻種の中で最初に全ゲノ ムが解読され, 広く研究されているシネコシスティス (Synechocystis sp. PCC 6803) は，PHBを合成すること が知られている（図2）。PHBは，糖代謝の下流で合成 され，解糖系の最下流でできるアセチル CoA から 3 段階 の反応で合成される。アセチル CoA からのPHB合成に は, PhaA, B, C, Eという4つのタンパク質が, 酵素とし て働く．最後の反応は，PHA シンターゼと呼ばれる酵 素（シネコシスティスの場合は $\mathrm{PhaC}$ と）であるが, 外来のPHA シンターゼをシネコシスティスに導入して 酵素活性を増大させても, PHB量が増加しないなど, PHBの増産には合成醳素を増やすだけでは不十分であ ることが知られている。このため，局所的に酵素活性を 増大させるだけではなく，糖代謝全体を活性化させ，特 に糖異化（糖の分解反応）を促進し，アセチル CoA な ど，PHBの基質の供給量を増やすことが重要であると 思われる.

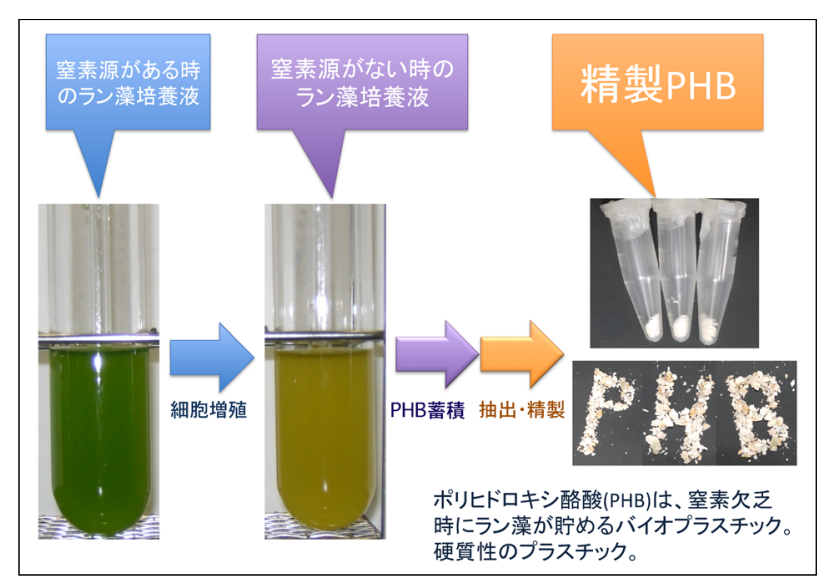

図2匹バイオプラスチックポリヒドロキシ酪酸（PHB） 


\section{今日の話題}

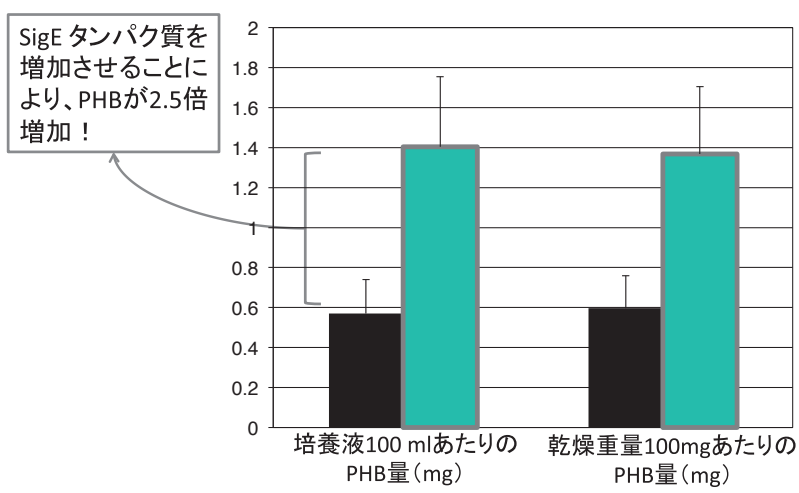

黒色:対照株

緑色:SigEタンパク質が増加した株

\section{図 3 - 窒素欠乏時のPHB量比較}

これまでの研究により，アセチルCoAの量を増加さ

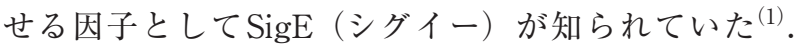
SigEは, RNAポリメラーゼと呼ばれる転写複合体タン パク質に含まれ，DNAとの結合を担うシグマ因子と呼 ばれるタンパク質ファミリーに属する。 SigEは, グリ コーゲンやグルコースの分解といった「糖異化」を担う 酵素群の遺伝子の発現を, 包括的に活性化する因子であ ることが知られている(1). $\mathrm{PHB}$ の基質であるアセチル CoA は，糖代謝経路の下流に位置し，実際にSigE過剰 発現株（SigEタンパク質を増加させたシネコシスティ ス株）では，アセチル CoAの量が約 2 倍に増加する ${ }^{(1)}$. このことから, SigEを用いることで, 代謝全体を改変 した上での PHB生産の可能性が示唆されていた。

$\mathrm{SigE}$ 過利発現株を詳細に解析した結果，糖代謝酵素 のみならず, PHA シンターゼのタンパク質量が増加し ていることがわかった ${ }^{(2)}$ 。この結果は, グリコーゲンか ら PHBまでの代謝経路が, SigEというタンパク質に よって包括的に制御されていることを意味する。実際 に，窒素欠そ時の $\mathrm{PHB}$ 量を調べたところ， SigE過剩発 現株では, 野生株に比べて PHB量が約 2.5 倍に増加して いることがわかった ${ }^{(2)}$ (図3)。一方で，PHBの分子量分 布や化学組成などは, SigE過剩発現によって変化しな いこともわかった ${ }^{(2)}$.
また, SigE過剰発現株では, 糖代謝とPHB生産だけ でなく, 細胞の直径や光合成活性 (酸素発生量), 水素 の生産量など, さまざまな変化が起こることがわかって いる ${ }^{(3)}$.

このようにわれわれは，代謝酵素遺伝子ではなく， シ グマ因子という転写に関与するタンパク質の遺伝子を改 変することで, ラン藻バイオプラスチックの増産に成功 した。また，ラン藻のバイオプラスチックと水素の生産 が，同じタンパク質によって制御されているという興味 深い事実も明らかになった。本研究では，転写制御因子 をたった一つ改変しただけで, 代謝や光合成, 細胞の形 態までも変化させることがわかった，今後はこのよう に，代謝酵素のみならず，種々の制御因子の改変を行う という新しい形の代謝工学が進んでいくと思われる.

1) T. Osanai, A. Oikawa, M. Azuma, K. Tanaka, K. Saito, M. Y. Hirai \& M. Ikeuchi : J. Biol. Chem., 286, 30962 (2011).

2) T. Osanai, K. Numata, A. Oikawa, A. Kuwahara, H. Iijima, Y. Doi, K. Tanaka, K. Saito \& M. Y. Hirai : DNA Res., 20, 525 (2013).

3) T. Osanai, A. Kuwahara, H. Iijima, K. Toyooka, M. Sato, K. Tanaka, M. Ikeuchi, K. Saito \& M. Y. Hirai : Plant J., 76, 456 (2013).

(小山内 崇, 科学技術振興機構さきがけ, 理化学研 究所環境資源科学研究センター)

プロフィル

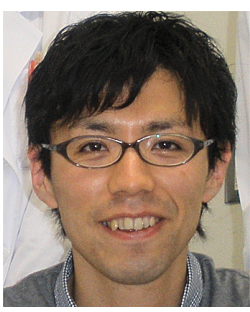

小山内 崇 (Takashi OSANAI)

$<$ 略歴 $>2002$ 年国際基督教大学教養学部 理学科卒業 $/ 2007$ 年東京大学大学院農学 生命科学研究科博士課程修了, 農学博士 同年日本学術振興会特別研究員 (PD) (東 京大学総合文化研究科) / 2010 年基礎科学 特別研究員 (理化学研究所植物科学研究 センター)／2011年JSTさきがけ専任研究 者（藻類バイオエネルギー領域）および客 員研究員 (理化学研究所環境資源科学研 究センター), 現在に至る<研究テーマと 抱負>ラン藻を用いた代謝工学を発展さ せ, 本当に環境に優しい藻類の物質・エネ ルギー生産系を構築することが夢＜趣味> ジョギング 